\title{
Knowledge Transfer and the Early Modern University: Statecraft and Philosophy at the Akademia Zamojska (1595-1627). By Valentina Lepri.
}

\author{
Leiden-Boston: Brill, 2019. 192 pp.
}

\section{Borbála Lovas}

Humanism in East Central Europe Research Group, Institute of Hungarian Literature and Cultural Studies, Faculty of Humanities, Eötvös Loránd University of Budapest, Múzeum krt. 4/A, H-1088 Budapest, Hungary; lovas.borbala@btk.elte.hu

The twenty-sixth volume of the Scientific and Learned Cultures and Their Institutions series is Valentina Lepri's new monograph on Akademia Zamojska, one of the most illustrious universities of East-Central Europe in early modern times. The slim and elegant volume offers the reader a full overview of the topic, focusing on the first three decades of the history of the institution. The first chapter of the book introduces the reader to the history of universities, the shaping of a Renaissance university within the Polish academic context and the formation and development of the Akademia. The second chapter presents the teaching community, the characteristics of teacher-training and the importance of Italian-Polish networking, as well as the relevance of the research journeys made by the educational staff. In the third chapter, Lepri discusses the curricula, the syllabuses and the texts in printed books and manuscripts connected to the different levels of education, with a focus on dialectics and philosophy, and their political use.

Although Polish researchers have been dealing with this topic for some time, their achievements were available only to a limited audience. Lepri's book therefore opens up the rich corpus and the research materials to the English-speaking audience, and gives a detailed description of the history of this particular institution, contextualizing the Akademia Zamojska within the international research field of early modern universities and academies.

The book gives the reader a wide overview of the Polish political and educational systems, as well as of ecclesiastical issues. And for the benefit of any researcher dealing with the East-Central European region, this study opens a new perspective for understanding the history of Poland and the surrounding countries, involving 
figures such as Emperor Rudolf II, King Henry III, Sigismund III Vasa, Maximilian III, Sigismund II Augustus, Popes Clement VIII, Gregory XIII and Pius V, papal legates and their circles, such as politicians and scholars. The main character in the history of the Akademia is Jan Zamoyski, former chancellor of Stephen Báthory, who devoted tremendous efforts to the organization of the institute, and generously financed the building of the campus in his newly built town of Zamość, "the northern Padua".

The institution received its university status from Pope Clement VIII on 24 October 1594, and opened its gates few months later, on 15 March 1595. Although it was undoubtedly under the authority of the Catholic Church, the Akademia was inclined towards the ideal of religious tolerance, and had only three faculties, arts, law and medicine, until 1648 when the theology faculty was founded. The five halls of residence of the students, following the example of other European, especially Italian universities, were divided by nationality: Polish, Lithuanian, Russian, Prussian-Livonian, and other foreign students. The Akademia, as a Polish experiment in schola civilis, had a rather hybrid educational system, inspired by various contemporary educational models. The volume shows the different cultural approaches and teaching methods by following the academic careers of the teachers, and introduces the reader to the regulations and study programs of the university. The history of the heterogeneous nobility and the unique political system also tells the story of this well-principled, ambitious strategy of giving the young members of the nobility a proper education, an academic training, and a sound basis for the performance of their duties on the national and international political stage.

In the first three decades of the history of the Akademia, forty-one professors joined the institution. Although the founder, Zamoyski, also studied in Italy, and was even elected rector of the Faculty of Law in Padua in 1563, he delegated to the new Polish university Szymon Szymonowic, a well-known intellectual of the period, who became the main figure in launching the Akademia. Under his direction the teachers of the first period started to arrive, first of all Jan Ursinus, Melchior Stefanowicz, and Wawrzyniec Starnigel, all of whom had studied in Kraków, followed by a more varied teaching body, with more Polish scholars connected to Kraków, represented by Mateusz Turski, Adam Burski, and Szymon Birkowski, and foreign scholars such as William Bruce, Domenico Convalis, and Adriaan van Roomen, later joined by Tomasz Drezner, Szymon Piechowicz, Jan Sechini, Kapser Scholz, Gaspar Trądkowski and others.

A particularly important resource for the educational system was the library of the institution. Its growing collection was based on donations by Jan Zamoyski and by professors such as Szymonowic, Birkowsky, Ursinus and Drezner, and was enlarged by gifts from Pope Gregory XIII, Sigismund II Augustus, and scholars such as Reinhold Heidenstein or Krzysztof Warszewicki. The collection was augmented 
by specially requested volumes connected to teaching needs or editorial activities. The latter were particularly important because the Akademia not only employed a chosen group of masters from Poland and the rest of Europe, but also attended to the needs of the teachers with the well-established library, and funded studies at foreign universities for the teaching staff. It also ran a printing house, which played a notable role in academic life, publishing the works of its own professors for educational use, as well as important texts of Polish literature and history: Szymon Szymonowic's Sielanki, influenced by Virgil, the Hercules Prodiceus, dedicated to Tomasz Zamoyski, the plays of Piotr Ciekliński, Ursinus' De ossibus humanis tractatus, the first work on human anatomy and osteology with Polish glosses, and the second edition of his Methodicae grammaticae libri quattor. The press also published legal works, like the new edition of the Statua Regni Poloniae in ordinem alphabeti digesta by Jan Herburt, the Farraginis actionum iuris civilis by Jan Cervus, the volumes of Juris provincialis quod Speculum Saxonum vulgo nuncupatur libri tres, the Juris Municipalis Majdeburgensis Liber, and the Promptuarium juris provincialis Saxonici. The first products of the printing house were the official document Professores Hippei Samosciani, and two Latin grammars, a few months before the privilege of printing was granted by Pope Clement VIII to the press in 1594, followed by grammar textbooks financed by Zamoyski, and over one hundred publications under the first three printers. The trilingual catechism, the Institutio christiana, prepared by Ursinus, Bruce and Stefanowicz, was published in 1597. New editions of works were also printed, like the Dionysii Halicarnassei De collocatione verborum graece et latine, or the Dialectica Ciceronis, edited by Birkowski and Burski, which became important foundations for the education of new generations of politicians who had to become "eloquent as an orator, but also had to know how to reason like a philosopher" (p. 115). A fascinating series of sub-chapters show us further editions of Burski, and the institution's approach to Aristotelianism, Neostoicism, Neoplatonism and Ciceronianism, offering the students of the university an overall perspective, involving other prints and textbooks like the Elementa seu loci ex Ciceronis libri desumpti quibus via ad philosophiam aperitur, or the Narrationes, sententiae, similia ex libris Marci Tullii Ciceronis, edited by Szymon Piechowicz. The list of publications and the editorial system of the printing press show the close cooperation amongst the professors, and the sophisticated organization of their autonomy, which was (apart from the Jesuit university in Vilnius), unique in the Polish-Lithuanian Commonwealth, and offer a focused view of the works as supporting materials of the educational programs in the Academia Zamojska. This argument is supported by the detailed analysis of the manuscripts kept today in the collection of the Biblioteka Ordynacji Zamojskiej, especially two volumes (once a single collection), a miscellany codex listed wrongly in the catalogue as 
Discorsi politici by Fabio Guicciardino, and another composite codex described by Paul Oskar Kristeller as "Reports of the Venetian ambassadors 1557-70", containing various texts, popular works connected to political topics and diplomatic matters. The discussed texts were almost without exception published in the Thesoro politico (printed first in 1589), of which the library of the university also kept volumes of the printed editions. The copies of the collection, offering a geopolitical overview of Europe, and containing examples based on contemporary politics, were most probably used alongside the printed versions as textbooks for studies on history, law, foreign politics, and international diplomacy. Other volumes, with personal notes and commentaries by the teachers and students, provide an insight into the study plans and lessons of the university, for example the teachings of Birkowski and Burski on Aristotle's Politics and Nicomachean Ethics, or Thomasz Drezner's notes on Cicero's De legibus. The book ends with an annex containing the deeds of foundation of the academy in Latin and in English, regarding its teaching program, followed by a rich bibliography on the topic.

The attempt by the Akademia Zamojska to establish close ties between Polish and European scholars, and between scholarly and political circles, while training a new generation of the Polish political elite, is thoroughly outlined in Lepri's volume. This work offers multiple reference points and corroborates every chapter with exhaustive and comprehensive notes and details. Despite this precise analysis, the text does not always offer a structure that is easy to follow and it is sometimes difficult to track down the discussed figures, their works and connections to the university. On the whole the monograph is a well-researched, informative, broad and useful work for researchers, and its clear style makes of it an enjoyable book for a wider readership as well.

https://orcid.org/0000-0002-4528-9296

(c) 2021 The Author(s). This is an open-access article distributed under the terms of the Creative Commons Attribution-NonCommercial 4.0 International License. 